Корендович В. С., к.т.н., доцент;

Наливайко А. Д., к.т.н., доцент;

Поляєв А. I.

Центр воєнно-стратегічних досліджень Національного університету оборони України імені Івана Черняховського, Київ

\title{
Підходи до створення та функціонування системи управління вимогами щодо розвитку спроможностей в органах управління складових сил оборони
}

\begin{abstract}
Резюме. Розглядаються можливі підходи до створення та функціонування системи управління вимогами (СУВ) щодо розвитку спроможностей в органах управління як Міністерства оборони та Збройних Сил України, так і інших складових сил оборони України.

Ключові слова: керівник СУВ; рецензент СУВ; менеджер СУВ; секретар СУВ.
\end{abstract}

Постановка проблеми. Питання удосконалення оборонного планування на основі спроможностей (ПОС) постали на порядку денному у силах оборони Україні [13] та стали одним із пріоритетів їх реформування. Система планування, яка сьогодні існує в державі, не відповідає вимогам сучасності щодо розвитку спроможностей сил оборони.

Кардинальна зміна пріоритетів при переході від існуючої системи оборонного планування до планування на основі можливостей 3 орієнтацією піi на кращі європейські стандарти має стати основою реформування національних сил оборони. Зазначене актуалізує питання підвищення ефективності ПОС за рахунок впровадження системи оцінювання спроможностей та управління вимогами щодо розвитку спроможностей у силах оборони.

Ступінь розробленості проблеми. Упродовж 2017-2018 років у Міністерстві оборони та Збройних Силах України розробляються та впроваджуються новітні підходи до ПОС [3], прийнята низка нормативно-правових актів 3 оборонного планування на основі спроможностей [4], розгорнута науково-пошукова діяльність щодо запровадження системи оцінювання спроможностей (ОС) та системи управління вимогами (СУВ) [5-6].

Провідними у формуванні та впровадженні системи управління вимогами у системі оборонного планування на основі спроможностей у силах оборони є праці I. C. Руснака [7], Р. І. Тимошенка, М. М. Лобка [8] та інших. Важлива роль у створенні методологічних основ системи управління вимогами у системі оборонного планування на основі спроможностей у силах оборони належить науково-дослідним установам Міністерства оборони (МО) та Збройних Сил (3С) України.

Мета статті. Визначення можливих підходів до запровадження системи управління вимогами до розвитку спроможностей в складових сил оборони України в контексті основних положень Стратегічного оборонного бюлетеня України [1] та з урахуванням досвіду держав-членів Альянсу.

Виклад основного матеріалу. ПОС $\epsilon$ важливим у створенні сучасних сил оборони. Водночас система ОС [6] $є$ ключовим елементом ПОС у складових сил оборони. Відомо, що опрацьовані в ході ОС пропозиції щодо розвитку окремої спроможності чи їх групи носять рекомендаційний характер. Їх реалізація має бути узгоджена 3 пропозиціями до інших спроможностей.

Зважаючи на зазначене виникає необхідність схвалення пропозицій щодо ОС, які надаються за складовими спроможностей (базовими компонентами спроможностей); визначення пріоритетів та завдань до їх подальшої реалізації. Ця робота буде проводитись у рамках функціонування системи управління вимогами (СУВ), яку доцільно запровадити в складових сил оборони. Як приклад на рис. 1 наведено структурну схему системи управління вимогами ПОС у МО та ЗС України.

Основними завданнями СУВ можуть бути:

забезпечення всебічного розгляду та оцінювання результатів ОС відповідними структурами складових сил оборони; визначення пріоритетності спроможностей в рамках кожної 3 
функціональних груп (ФГ), а також у рамках усіх ФГ [5];

супроводження реалізації прийнятих рішень щодо розвитку спроможностей.

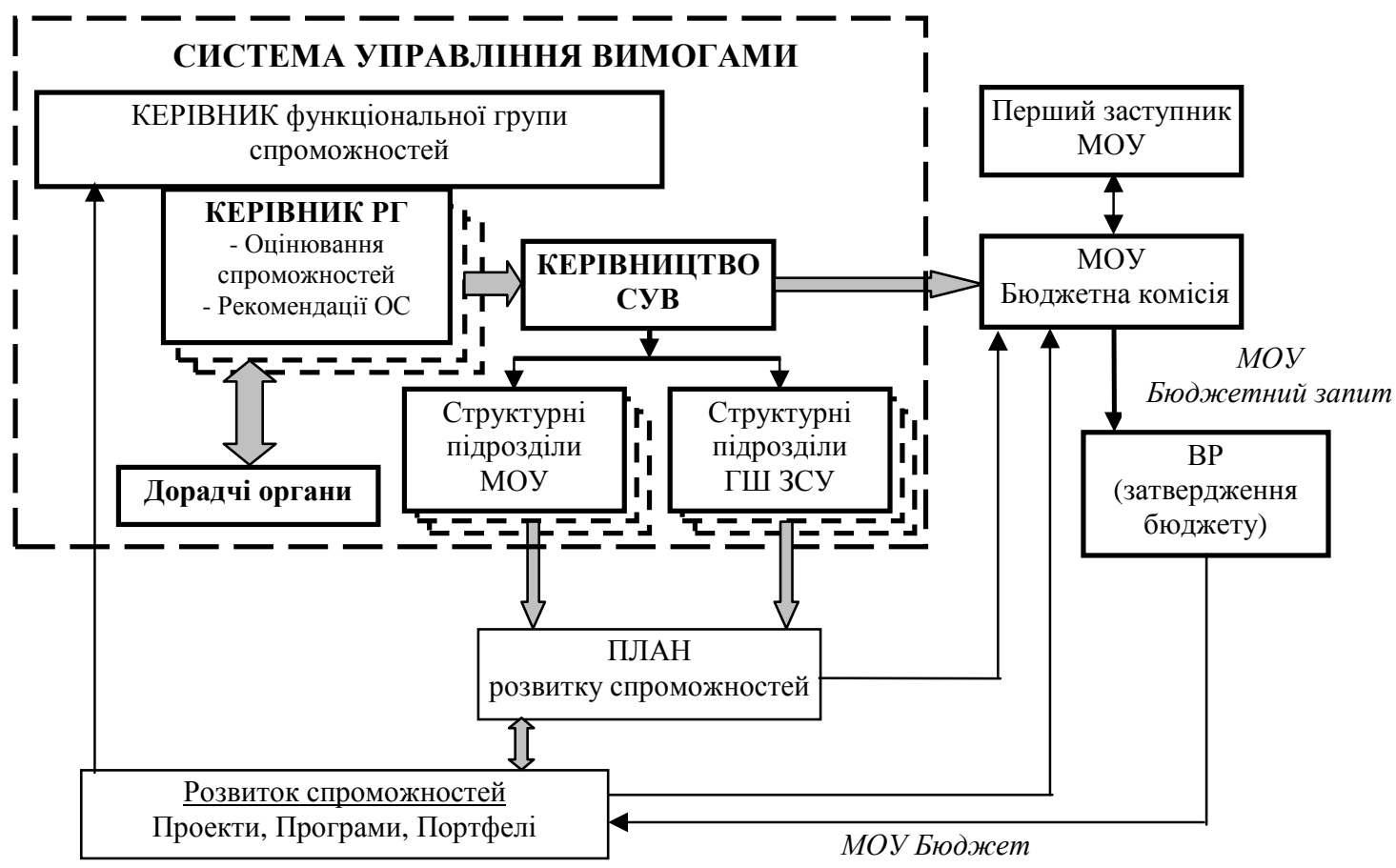

Рис. 1. Структурна схема системи управління вимогами ПОС у МО та ЗС України

Діяльність СУВ має відповідати таким принципам:

відповідальність певним стандартам (які мають бути єдиними по відношенню до всіх документів, що надаються до СУВ);

забезпечення єдиного підходу при розгляді результатів (пропозицій) всіх ОС;

прозорість при розгляді (виконавці мають знати де i як опрацьовується їх документ, внесений на розгляд).

Виходячи із зазначеного, в СУВ реалізуються три основні процеси: до СУВ; проведення ОС та внесення пропозицій

розгляд та оцінювання пропозицій ОС фаховими робочими групами (експертами); менеджмент рішеннями.

У СУВ всебічно та колегіально розглядаються пропозиції ОС, фахівці можуть висловлювати певні заперечення щодо їх придатності, реалістичності та прийнятності, але остаточне рішення приймається однією особою (Керівником СУВ).

Загальне керівництво СУВ доцільно здійснювати одному із заступників керівника органу управління (ОУ) складової сил оборони, діяльність якого буде підтримуватися відповідними структурними підрозділами. Стосовно ЗС України такою особою може бути заступник Начальника ГШ ЗС України.
СУВ також має здійснювати моніторинг виконання прийнятих рішень щодо розвитку спроможностей:

через розвиток складових спроможностей (базових компонентів спроможностей);

у рамках проведення наукових досліджень;

у ході програмування та бюджетування, закупівлі, експериментування, реалізації політики розвитку СО в цілому.

Структура СУВ включатиме: керівництво (визначені відповідні посадові особи для виконання керівних функцій в СУВ); визначені структурні підрозділи (штатні або тимчасово сформовані) та експерти, які діють як на постійній, так і на тимчасовій основі.

Можливий порядок розгляду пропозицій в СУВ наведено на рис. 2.

Першою 3 посадових осіб, яку доцільно віднести до керівництва, слід назвати Керівником робочої групи (РГ), який $\epsilon$ ініціатором проведення ОС, очолює цей процес і підписує відповідні рекомендації ОС [9-11].

Наприклад, при оцінюванні спроможностей артилерії Керівником РГ ОС доцільно призначати начальника ракетних військ і артилерії.

На початковому етапі, функціонування СУВ у ході ОС, Керівник РГ визначає вимоги до спроможностей та пропозиції щодо їх розвитку. На наступному етапі (у подальшому) документи (для узгодження в рамках 
проходження штабних процедур) сил оборони. направляються Секретарю СУВ ОУ складової

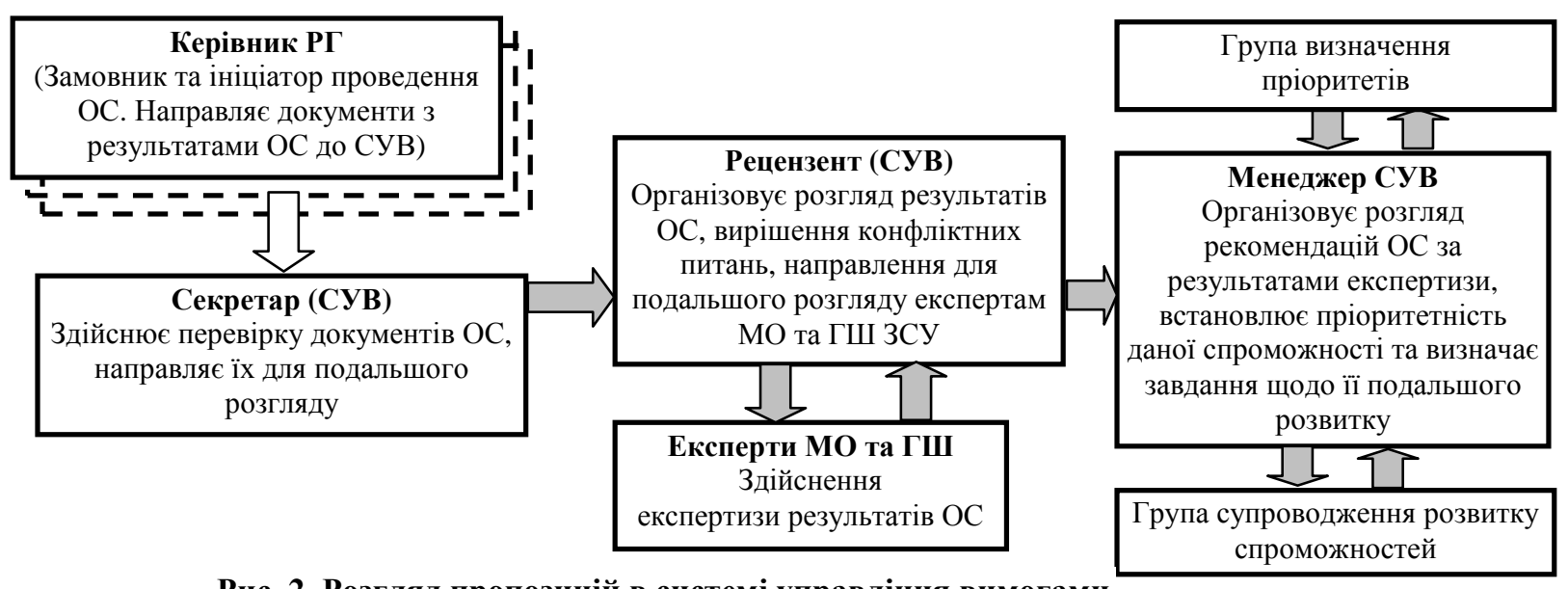

Рис. 2. Розгляд пропозицій в системі управління вимогами

Секретар СУВ ОУ складової ОС перевіряє відповідність внесених на розгляд документів ОС встановленим вимогам. У випадку невідповідності документа ОС формальним вимогам Секретар СУВ призупиняє його розгляд та повертає документи ОС Керівнику РГ. У разі відповідності документів вимогам, вони передаються в групу рецензування (Рецензенту). Секретар СУВ має підпорядкуватися безпосередньо Рецензенту СУВ.

Рецензент СУВ [12] організовує розгляд результатів ОС, вирішення конфліктних питань, що виникають у ході розгляду пропозицій ОС, та направляє для подальшого розгляду експертам зацікавлених структурних підрозділів або експертам ФГ спроможностей. Рецензент за своїм статусом має бути не нижче керівників функціональних груп спроможностей. 3 іншого боку Рецензенту доцільно бути співголовою в керівництві ФГ, адже така співпраця $\epsilon$ доцільною для досягнення виважених $\mathrm{i}$ збалансованих рішень.

3 іншого боку Рецензенту доцільно бути співголовою у підгрупі визначення пріоритетів i працювати спільно 3 Менеджером, який відповідає за пріоритизацію спроможностей.

Рецензентом, як правило, призначається представник структурного підрозділу, що займається розвитком спроможностей, який входить до ОУ складової сил оборони. Бажано, щоб він був зі структурного підрозділу, який за своїм статусом не нижчий ніж ті, з яких визначені керівники функціональних спроможностей.
Тісна взасмодія Рецензента 3 Менеджером, який $є$ представником органу управління складової сил оборони, також сприятиме об'єктивному розгляду наданих пропозицій та прийняттю всіх наступних рішень.

У Рецензента повинні бути повноваження щодо можливості залучення представників ОУ складової сил оборони для виконання дорадчих функцій.

Важливим питанням $\epsilon$ призначення керівництва функціональних груп та визначення їх стосунків із СУВ. Незважаючи на те, що рішення приймає Рецензент, майже завжди воно обговорюється 3 керівником ФГ, адже він $є$ відповідальним фахівцем за даним напрямом. Значними при прийнятті рішень $\epsilon$ i дорадчі органи (групи).

Дорадча група не є постійним органом. До іiі складу призначаються представники 3 відповідних функціональних груп, старші офіцери з ГШ ЗС України, МО та видів ЗС України, інших установ (які $є$ експертами у визначеній галузі) з однією метою - прозоро та об' єктивно розглянути документ, що містить пропозиції ОС, та провести їх оцінку. При цьому слід зазначити, що окремі представники у керівництві ФГ мають працювати на постійній основі (можуть бути штатними).

Після отримання позитивних висновків щодо експертизи експертами функціональних груп та зацікавленими структурними підрозділами складової сил оборони, які забезпечують прийняття рішення Рецензентом СУВ, документи ОС погоджуються та направляються до групи Менеджера СУВ. Менеджер забезпечує визначення пріоритету спроможності у ФГ, а також пріоритету спроможності серед всіх груп спроможностей; підписує рекомендації ОС для реалізації; 
здійснює нагляд за виконанням (включаючи оцінку виконання) прийнятих рішень. Він же $є$ головою в групі з визначення пріоритетів.

Доцільно Менеджером СУВ призначити офіцера (генерала або адмірала) чи цивільну особу зі структурного підрозділу ОУ сил оборони, який займається розвитком спроможностей. Менеджер також повинен мати певні повноваження щодо постановки завдань 3 розвитку спроможностей у складових $\mathrm{CO}$, а також прямі владні повноваження над посадовими особами, які супроводжують та оцінюють реалізацію розвитку спроможностей.

Менеджер СУВ [10] організовує визначення пріоритетності спроможностей, що розглядаються, та визначає завдання щодо ïх подальшого розвитку. Ця робота здійснюється за підтримкою двох підгруп: підгрупи 3 пріоритизації i підгрупи супроводження та оцінювання реалізації спроможностей.

Підгрупа 3 пріоритизації розглядає та оцінює всі рекомендації документа ОС та визначає пріоритетність реалізації спроможностей в межах окремих ФГ та серед всіх ФГ. Вона надає пріоритет окремим спроможностям та пропозиції щодо їх подальшого розвитку.

Група визначення пріоритетів працює не на постійній основі. Вона збирається декілька разів на рік, адже визначений пріоритет не може часто змінюватися, а тільки в окремих випадках важливих змін (подій). Наприклад, зміна керівництва держави або МО та ГШ 3С України, яка може обумовити певну зміну пріоритетів, або коли в ході ОС опрацьовані радикальні пропозиції, які доцільно врахувати в існуючих пріоритетах. До складу групи мають входити: на правах співголів Менеджер та Рецензент, керівники кожної ФГ (з правом голосу), інші фахівці із зацікавлених структур (без права голосу). Процес визначення пріоритетів має бути прозорим.

Визначення пріоритетності розвитку спроможностей може здійснюватися за допомогою рейтингу, оцінювання якого проводиться експертним шляхом за методикою, яка враховує: ймовірність виникнення завдання в рамках сценарію та можливий вплив на процес досягнення цілі у разі невиконання цього завдання; затребуваність певної спроможності для виконання визначеного завдання та ступінь негативного ефекту на виконання завдання через незастосування спроможності.
Група супроводження та оцінювання реалізації спроможностей займається питаннями реалізації спроможностей (після визначення пріоритету спроможностей i постановки завдань щодо їх розвитку), в подальшому вона супроводжує виконання прийнятих рішень щодо їх розвитку. Доцільно ці функції надати відповідному структурному підрозділу.

Група також супроводжує виконання рекомендацій відповідно до завдань, визначених Менеджером СУВ, за критеріями своєчасності виконання рекомендацій та надання бюджетних асигнувань; оцінює прийнятність реалізації планів розвитку спроможностей для досягнення визначених показників. Група може бути постійним підрозділом, підпорядкованим Менеджеру СУВ. До неї можуть також залучатися на тимчасовій основі фахівці 3 ФГ, які безпосередньо зацікавлені у розвитку спроможності ФГ відповідно до визначених показників.

Менеджер підписує документ 3 визначеними завданнями та надає його посадовій особі, що здійснює загальне керівництво СУВ (наприклад, у ГШ ЗС України нею може бути Заступник начальника ГШ ЗС України), а також керівнику РГ, який надав пропозиції з ОС. У подальшому пропозиції подаються до Бюджетної комісії ОУ складовій сил оборони для розгляду.

Зазначена модель роботи СУВ є надто простою, проте, більш складним завданням $€$ визначення відповідальних посадових осіб та структурних підрозділів в ОУ складових сил оборони, які будуть реалізовувати зазначені функції СУВ.

Велике значення має призначення посадових осіб до структури СУВ, які залучаються до виконання зазначених вище функцій. При цьому важливо, щоб ці особи знаходились у визначеній системі підпорядкування за службовою вертикаллю. Доцільно не створювати нові структурні підрозділи, а максимально використати існуючі структури, які вже вирішують завдання ПОС, i за необхідності, уточнити (змінити) функціональні обов'язки їх посадових осіб. Зазначений підхід дасть змогу гармонізувати діяльність структурних підрозділів ОУ складових сил оборони, забезпечивши їм більш ефективну спільну діяльність.
Визначення змісту
діяльності функціональних груп спроможностей здійснюється переважно у структурних підрозділах органу управління сил оборони. 
Формування політики щодо розвитку та забезпечення спроможностей здійснюється в ОУ сил оборони. Виходячи 3 цього, Рецензентом та Менеджером СУВ мають бути представники ОУ складової сил оборони. При цьому Менеджер СУВ має бути спроможним здійснювати взаємодію з посадовими особами, що забезпечують планування та розвиток спроможностей у функціональних групах. Не виключено, що функції Рецензента та Менеджера СУВ може виконувати одна особа, але при цьому буде виникати багато питань у процесі формування політики розвитку спроможностей та її ресурсної підтримки.

Отже, за підсумками оцінювання спроможностей в рамках системи ОС та розгляду їх результатів у СУВ у складових сил оборони з'являються обгрунтовані оцінки стану спроможностей на довгострокову перспективу, які дають змогу визначити напрями розвитку спроможностей за їх складовими.

Слід зазначити, що більшість рекомендацій за підсумками ОС та розгляду їх в СУВ не пов'язані із значними матеріальними рішеннями. Тому вони можуть бути враховані в рамках коротко- та середньострокового планування після розгляду бюджетною комісією.

Проте матеріальні рішення, пов'язані 3 вартісною закупівлею ОВТ, НДКР, радикальною модернізацією, потребує додаткового аналізу та апробації перш ніж буде прийнято рішення щодо їх реалізації в рамках окремих програм.

Висновок. Таким чином, запропоновані підходи до створення та функціонування системи управління вимогами щодо розвитку спроможностей дають змогу поєднати процеси 3 оцінювання як окремих спроможностей, так і груп (функціональних груп) спроможностей в ОУ складових сил оборони в єдиний процес. Такий підхід забезпечить обгрунтовану та якісну підготовку документів 3 оцінювання спроможностей та їх розвитку у складових сил оборони, функціонально об'єднає учасників процесу оцінки спроможностей, надасть можливість підвищити відповідальність посадових осіб за реалізацію розвитку спроможностей.

\section{СПИСОК ВИКОРИСТАНОЇ ЛІТЕРАТУРИ}

1. Указ Президента України від 26 травня 2015 року № 287/2015 "Про рішення Ради національної безпеки і оборони України від 5 травня 2016 року Про Стратегію національної безпеки України”.

2. Указ Президента України від 24 вересня 2015 року № 555/2015 "Про рішення Ради національної безпеки і оборони України від 2 вересня 2016 року “Про нову редакцію воєнної доктрини України".

3. Указ Президента України від 14 березня 2016 року № 92/2016 “Про рішення Ради національної безпеки і оборони України від 4 березня 2016 року "Про Концепцію розвитку сектору безпеки i оборони України”.

4. Указ Президента України від 6 червня 2016 року № 240/2016 “Про рішення Ради національної безпеки і оборони України від 20 травня 2016 року "Про стратегічний оборонний бюлетень України".

5. Рекомендації з оборонного планування на основі спроможностей в МО та ЗС України, затверджені Міністром оборони України 13.06.2017 № 5789/3/3. Режим доступу http://www.mil.gov. ua/content/ other/Recommendationson_CBP_120617 pdf

6. Рекомендації 3 порядку організації проведення оцінювання спроможностей у Збройних Силах України, затверджені Міністром оборони України 07.12.2017.

7. Руснак I. С., Петренко А. Г., Яковенко А. В., Романюк I. М., Кохно В. Д./ Оборонне планування на основі спроможностей: особливості та перспективи впровадження // Наука і оборона. 2017, - № 2. - C. 3-10.

8. Тимошенко Р. І., Лобко М. М., Бочарніков В. П., Свєшніков С. В. Оборонне планування: загальна логіка, структура та взаємозв'язок документів// Наука і оборона. - 2015. - № 2. - С. 15-21.

9. Коди спроможностей та вимоги до спроможностей штабів стратегічного командування НАТО з операцій та стратегічного командування НАТО з трансформації (СК-О ТА СК-Т) від 26 січня 2016 року.

10. Capabilities-Dased Assessment (CBA). User's Guide. Version 3. Force Structure, Resources, and Assessments Directorate (JCS J-8). March 2009. Joint Chiefs of Staff. USA.

11. Joint Capabilities Integration And Development System (JCIDS). Chairman Of The Joint Chiefs Of Staff Instruction. J-8 CJCSI 3170.01I Distribution: A, B, C, S 23 January 2015. 
Корендович В. С., к.т.н., доцент;

Наливайко А. Д., к.т.н., доцент;

Поляев А. И.

Центр военно-стратегических исследований Национального университета обороны Украины имени Ивана Черняховского, Киев

Подходы к созданию и функционированию системы управления требованиями по развитию способностей в органах управления составляющих сил обороны

Резюме. Рассматриваются возможные подходы к созданию и функционированию системы управления требованиями по развитию возможностей в органах управления как Министерства обороны и Вооруженных Сил Украины, так и других составляющих сил обороны Украины.

Ключевые слова: руководитель СУВ; рецензент СУВ; менеджер СУВ; секретарь СУВ.

V. Korendovych, PhD (Technical), associate professor;

\section{A. Nalivayko, PhD (Technical), associate professor;}

A. Poliayev

Center for Military and Strategic Studies of the National Defence University of Ukraine named after Ivan Cherniakhovskyi, Kyiv

Some Approaches to Establish and Functioning of the Requirements Management System in the Framework of Capability Based Planning of the Defence Forces

Resume. Possible approaches to the creation and functioning of the requirements management system for the development of capabilities in the Ministry of Defence and the Armed Forces of Ukraine as well as in other components of the Ukrainian Defense Forces are considered.

Keywords: supervisor of RMS; reviewer of RMS; manager of RMS; secretary of RMS. 